\title{
International Committee on Systematic Bacteriology Subcommittee on the Taxonomy of Pseudonocardiaceae
}

\author{
Minutes of the Meeting, 4 July 1994, Prague, Czech Republic
}

Minute 1. Call to order. The meeting was called to order at 2:00 p.m. on 4 July 1994 by Chairperson M. Goodfellow.

Minute 2. Record of attendance. The members present were M. Goodfellow (Chairperson) and D. P. Labeda (Secretary). Apologies for absence were received from T. M. Embley, S.-B. Kim, R. M. Kroppenstedt, T. P. Preobrazhenskaya, and J.-S. Ruan.

Minute 3. New members. Two new members were nominated to serve on the subcommittee, J.-S. Chun (Republic of Korea) and T. Kudo (Japan).

Minute 4. Current membership. The current membership of the subcommittee is as follows: M. Goodfellow (Chairperson), Liverpool, United Kingdom; D. P. Labeda (Secretary), Peoria, Ill.; S.-B. Kim, Taejon, Republic of Korea; T. M. Embley, London, United Kingdom; R. M. Kroppenstedt, Braunschweig, Germany; and J.-S. Ruan, Beijing, People's Republic of China.
Minute 5. Minimal descriptions. A preliminary plan of work for drafting minimal descriptions for the genera in the family Pseudonocardiaceae was developed. Possible contributors to this effort, including both members and nonmembers of the subcommittee, were identified and will be contacted by the Secretary regarding their participation.

Minute 6. Next meeting. The next meeting of the subcommittee will be held during the International Union of Microbiological Societies 8th International Congress of Bacteriology and Applied Microbiology, which is to be held in Jerusalem, Israel, in August 1996.

Minute 7. Adjournment. The meeting was adjourned at 2:25 p.m. on 4 July 1994.

David P. Labeda, Secretary 